\section{PRODUCTION}

ENGINEERING ARCHIVES
2014, Vol. 5, No 4, pp 18-21

ISSN 2353-5156

ISSN 2353-7779 (print version)

(online version)

Article history: $\quad$ Received: 03.12.2014

Accepted: 19.12.2014

Online: 31.12 .2014

Available online on: http://www.qpij.pl

Exist since $4^{\text {th }}$ quarter 2013

\title{
Grinding of stainless steel X6CrNiMoTi and its final roundness
}

\author{
Nataša Náprstková ${ }^{1}$, Martin Novák ${ }^{2}$, Jaromír Cais ${ }^{3}$ \\ ${ }^{1}$ Faculty of Production Technology and Management, Jan Evangelista Purkyně University in Ústí nad Labem, Pasteurova 1, 40096 Ústí nad \\ Labem, Czech Republic, +420 475285 513, naprstkova@ fvtm.ujep.cz \\ ${ }^{2}$ Faculty of Production Technology and Management, Jan Evangelista Purkyně University in Ústí nad Labem, Pasteurova 1, 40096 Ústí nad \\ Labem, Czech Republic, +420 475285 536, novak@fvtm.ujep.cz \\ ${ }^{3}$ Faculty of Production Technology and Management, Jan Evangelista Purkyně University in Ústí nad Labem, Pasteurova 1, 40096 Ústí nad \\ Labem, Czech Republic, +420 475285 542, cais@ fvtm.ujep.cz
}

\begin{abstract}
Machining of stainless steels is often an important technology used in production. Products made from these materials are very often used in mechanical engineering, and quality of work-piece surface after machining respective grinding is one of the important parameters that to us speak about the quality of the machining process. One of these parameters that can to give evidence about the quality of the surface is for rotating part the roundness. Its measurement is one of the important sources of information about how cutting conditions can affect the quality of the machined surface. The paper deals with the influence of cutting conditions when grinding steel X6CrNiMoTi (EN ISO) on the roundness of a machined surface.
\end{abstract}

Key words - roughness, analyses, stainless steel, grinding

\section{Introduction}

This paper deals with an experiment that was conducted at FPTM JEPU. The stainless steel was grinded under certain cutting conditions and then the achieved geometric accuracy of machined surfaces was evaluated, namely roundness.

Grinding technology belongs with the honing, lapping and super-finishing to abrasive finishing methods. In terms of technological outputs of this technology, parameters of achieved precision on machined surfaces are particularly important (MARINESCU I. 2007).

Because the work-piece material was stainless steel, it is necessary to briefly characterize these materials. Stainless steels belong to a group of difficult to machine materials, mainly due to their tendency to harden in cold, have low thermal conductivity and good toughness. They are used in food, chemical, textile and automotive industries and in recent years also in the construction industry, particularly as architectural elements (NOVÁK M. 2011; KocMAN K. 2004; KOCMAN K. 2012).

Geometric accuracy of components is prescribed for manufacturing drawings, mostly to functional surfaces of machined parts. Using standard markings may be required for example maintaining alignment, roundness, cylindricity, perpendicularity or waviness in the prescribed tolerance fields. Requirements for the accuracy of machined surfaces must be taken into account in the design of the given component and material selection. Based on the shape, complexity, requirements for accuracy and work-piece material also 
depends on the production technology used, the sequence of operations, choice of machine tools, the use of fixtures, cutting tools and all other necessary equipment for the manufacturing of components. (VALÍČEK J. 2008; MÁDL J. 2008; JERSÁK J. 2012).

The required geometric accuracy of manufactured components must meet all requirements for functionality, durability and smooth running of manufactured components, equally important is its impact on the economics of production (NOVÁK M. 2001; ROKYTA L. 2012). In the actual process of machining accuracy is affected, especially roundness and cylindricity. Both of these geometric accuracy parameters may be affected by the system vibrations of the machine - tool work-piece - product that can be caused by unstable tool rigidity or insufficient clamping or work-piece material inhomogeneity (NOVÁK M. 2012; MÁDL J. 2012).

A deterioration of roundness can also occur, for example, during machining of the work-piece with a circular cross section after cold drawn. Thus, the semifinished product already has differences in geometric accuracy, which may at a subsequent machining, especially when roughing, increase. This phenomenon is referred to as a "copying." Waviness can also be accompanied by other changes in surface integrity, such as changes in surface roughness and the change of residual stresses. In terms of geometric accuracy on the cutting machines and the tool, still increasing demands are placed, especially their stiffness and accuracy. A tool holder should prevent its vibration and its stiffness should be consistent in depth and cut all of the time. The work-piece should be clamped sufficiently to prevent the oscillation, in terms of material properties the work-piece material should be as homogeneous as possible (DUGIN A. 2013).

Research of the impact on the grinding surface was implemented specifically for the material X6CrNiMoTi.

\section{Experiment}

As already mentioned above, chrome-nickel austenitic steel marked 1.4571 (X6CrNiMoTi) was machined according to EN 10088-1. This steel has a tensile strength Rm 520-690 MPa. Machining of test samples was realized on a grinding machine BU-16. Machined surfaces were acquired by plunge cut grinding. In the course of the experiment two types of grinding wheel were used with different abrasive grain and hardness. When machining the test sample cutting fluid Emulkat Al $4000 \mathrm{CZ}$ was used. Used cutting fluid does into contain chlorine, which makes it environmentally friendly disposal. Cutting conditions for individual test samples are presented in Table 1.

Tab. 1 Cutting conditions of experiment

\begin{tabular}{|c|c|c|c|c|}
\hline $\begin{array}{l}\text { Method } \\
\text { of } \\
\text { grinding }\end{array}$ & $\begin{array}{c}\text { Grinding } \\
\text { Wheel }\end{array}$ & $\begin{array}{c}\text { Cutting } \\
\text { speed } \\
{\left[\mathrm{m} . \mathrm{s}^{-1}\right]}\end{array}$ & $\begin{array}{c}\text { Speed of } \\
\text { workpiece } \\
{\left[{\left.\mathrm{m} . \mathrm{min}^{-1}\right]}^{-1}\right.}\end{array}$ & $\begin{array}{c}\text { feed } \\
\text { speed } \\
\mathbf{v}_{\mathrm{f}}, \\
{\left[\begin{array}{c}\mathrm{mm}_{\mathrm{m}}{ }^{1} \text { min } \\
\left.{ }^{-}\right]\end{array}\right.} \\
\end{array}$ \\
\hline \multirow{8}{*}{ 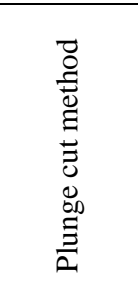 } & \multirow{4}{*}{ せ } & \multirow{2}{*}{35} & \multirow{8}{*}{20} & 0.17 \\
\hline & & & & 0.26 \\
\hline & & \multirow{2}{*}{40} & & 0.17 \\
\hline & & & & 0.26 \\
\hline & \multirow{4}{*}{ 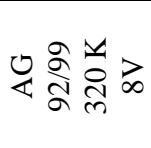 } & \multirow{2}{*}{35} & & 0.17 \\
\hline & & & & 0.26 \\
\hline & & \multirow{2}{*}{40} & & 0.17 \\
\hline & & & & 0.26 \\
\hline
\end{tabular}

When machining the test samples two grinding wheels were used designated AG 92/99 $150 \mathrm{~K} \mathrm{9V}$ and AG 92/99 320 K 8V. (JUSKO, O. 2010)

Wheel AG $92 / 99150 \mathrm{~K}$ 9V is made from $30 \% \mathrm{SG}$ (Seeded gel) grain of very fine grain 150. It is a soft wheel with a very porous structure with a ceramic bond. Grinding wheel AG 92/99 $320 \mathrm{~K} 8 \mathrm{~V}$ is also formed from abrasive with $50 \%$ SG grain. Abrasive grains are particularly fine, again it is a soft wheel. The wheel structure is porous and the wheel binder is ceramic.

\section{Roundness measuring}

Measuring of deviations from circularity was carried out in the laboratory of precision measurement at the FPTM JEPU in Ústí nad Labem. A measuring device Hommel tester Form 1000 was used. The measured values were averaged and it was determined the medium standard deviation (OsICKA K. 2009; KALINCOVA D. 2010).

The first was analyzed roundness for grinding wheel AG92/99 $150 \mathrm{~K}$ 9V. Fig. 1 shows an example of the transverse waviness (roundness), which was 
achieved by plunge cut grinding when the cutting speed was $35 \mathrm{~m} . \mathrm{s}^{-1}$ and the size of the infeed was 0.26 $\mathrm{mm} \cdot \mathrm{min}^{-1}$. These courses were measured for all samples (KALINCOVÁ D. 2010).

The first was analyzed roundness for grinding wheel AG92/99 $150 \mathrm{~K} 9 \mathrm{~V}$.

The graph in Fig. 1 shows a summary of measured values depending on the cutting conditions. From it, it is clear that in both cases, increasing the cutting speed from $35 \mathrm{~m} . \mathrm{s}^{-1}$ to $40 \mathrm{~m} . \mathrm{s}^{-1}$, and after reducing the size of the feed from $0.26 \mathrm{~mm} \cdot \mathrm{min}^{-1}$ to $0.17 \mathrm{~mm} \cdot \mathrm{min}^{-1}$, there was an increase of roundness deviation and the biggest decline in the value of circularity of $76 \%$ reduced the size of infeed for cutting speed of $35 \mathrm{~m} \cdot \mathrm{s}^{-1}$.

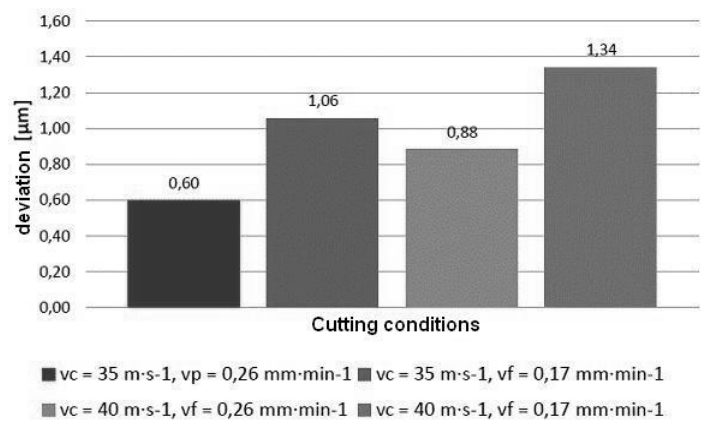

Fig. 1 The deviation from roundness depending on the cutting conditions, GW AG 92/99 $150 \mathrm{~K} 9 \mathrm{~V}$.

The graph shows a significant effect of infeed size on the deviations size from circularity when by its reducing the deviation increased on average $64 \%$. Increased cutting speed from $35 \mathrm{~m} . \mathrm{s}^{-1}$ to $40 \mathrm{~m} . \mathrm{s}^{-1}$ increased the deviation of $37 \%$. The deterioration of the deviation from circularity value could occur, for example, by increasing the vibration of system machinetool-workpiece-fixture which was caused by excitation force or unbalancing of the grinding wheel or input waviness of the machined surface.

The roundness after grinding by grinding wheel AG 92/99 $320 \mathrm{~K} \mathrm{8V}$ was also measured and analysed.

Then the measured values were summarized in the graph in Fig. 3. The most significant change to reduce this parameter of $37 \%$ was achieved by increasing the cutting speed from $35 \mathrm{~m} . \mathrm{s}^{-1}$ to $40 \mathrm{~m} . \mathrm{s}^{-1}$ for the infeed $0.17 \mathrm{~mm} \cdot \mathrm{min}^{-1}$. Conversely, a higher deviation of $31 \%$ was measured for reducing of infeed from 0.26 $\mathrm{mm} \cdot \mathrm{min}^{-1}$ to $0.17 \mathrm{~mm} \cdot \mathrm{min}^{-1}$ at cutting speed $35 \mathrm{~m} \cdot \mathrm{s}^{-1}$.
After calculating the average changes in the monitored parameter it was possible to conclude that an increase in cutting speed was achieved and $30 \%$ reduction in deviations from roundness. This phenomenon could be caused by a more appropriate overlay of grinding wheel revolutions and the work-piece after increases in cutting speed. In contrast, the reducing of the infeed size seemed a negative influence, the deviation in average deteriorated by $18 \%$. It could be caused, for example, by increasing the vibration system of machine-tool-workpiece-fixture.

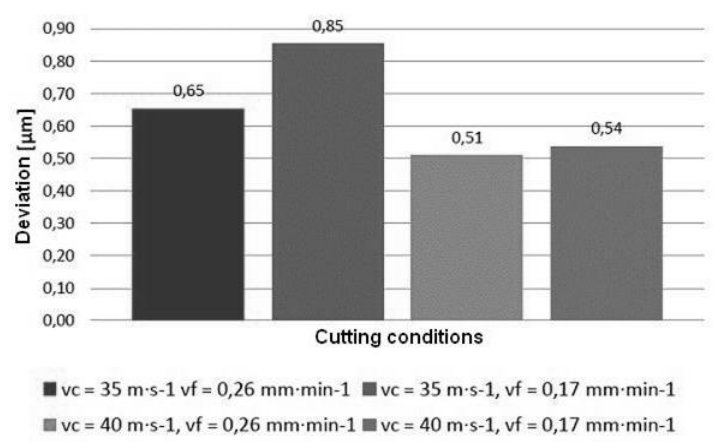

Fig. 2 The deviation from circularity, depending on the cutting conditions, GW AG92/99 $320 \mathrm{~K} 8 \mathrm{~V}$.

\section{Conclusions}

Machined surfaces were analyzed by focusing on the geometric accuracy of the work-piece, in particular, the analysis of deviations from roundness. The first work-piece analyzed after machining grinding wheel AG92/99 $150 \mathrm{~K} \mathrm{9V}$, grinding was carried out by the plunge cut method. The result of the experiment showed adverse effects of cutting speed increasing the deviations from the roundness parameter, when it deteriorated. Deterioration was also caused by a reduction of the infeed size. This may be caused by the vibration of system machine - tool - work-piece - fixture for higher machine speed. When comparing the mutual influence changes of the cutting speed and the infeed it has been found that resizing of the infeed should have a bigger influence on monitored parameters than the change of cutting speed

The workpiece after machining by grinding wheel AG92/99 $320 \mathrm{~K} \mathrm{8V}$ was also analyzed, grinding was performed again as a plunge cut method and under the same cutting conditions as in the previous wheel. 
There was an increase in the rate of improvement of the observed parameter. Reduction of infeed size worsened the values of deviations from roundness for the test samples. As in the previous analysis, a greater influence on the surface quality had the resize of the infeed over change of cutting speed. However, while in the previous analysis impairment of infeed occurred in average to the deterioration of surface parameters, this time reduction of the infeed had a positive impact on the quality of the surface.

\section{Acknowledgement}

Above mentioned results were created by means of the project CZ.1.07/2.3.00/30.0028 in JEPU in Usti nad Labem with name "Materials and Human Resources for Enviroment" and by support of V16 at FPTM JEPU.

\section{References}

1. Dugin A., PoPOV A. 2013 Increasing the accuracy of the effect of processing materil and cutting tool wear on the ploughingforce values. Manufacturing Technology, Vol 13, No.2, pp.169-173, ISSN 1213-2489.

2. JERSÁK J. 2012 Vliv dynamického vyvážení brousicího kotouče na drsnost povrchu obrobených součástí (Effect of dynamic balancing of the grinding wheel on the surface roughness of machined components). Strojírenská technologie (In Production Technology), Vol.17, No.1,2, p.27-33, ISSN 1211-4162.

3. JUSKO O. Vývoj a inovace brousicich nástrojů (Development and innovation of grinding tools). Strojírenská technologie (Production Technology),. Vol.15, No.1, 2010. p. 17-22, ISSN 1211-4162.

4. KALINCOVÁ D. 2010 Skušanie mechanických vlastností materiálov - prehlad meracich metod a zariadeni (Testing of mechanical properties of materials overview of measuring methods and devices). KEGA 3/6370/08., TU vo Zvolene, Zvolen.,. p.13-26.

5. KOCMAN K. 2004 Specialni technologie obrabeni (Special technologies for cutting). Brno, CERM.

6. KOCMAN K. 2012 Optimalizace dokončovacích operaci výrobnich procesù (Optimizing of finishing operations of manufacturing processes). Strojírenská technologie
(Production Technology), Vol.17, No.3, p.164-169, ISSN 1211-4162.

7. KuŚMIERCZAK S., SvobodovÁ J. 2014. Macroscopic quality evaluation of lacquered steel sheets. Production Egineering Archives. Vol. 2(1), p.26-30.

8. MÁdL J., HoleŠOVsKÝ F. 2008 Integrita obrobených povrchů z hlediska funkčnich vlastností (The integrity of the machined surfaces in terms of functional properties). Ústí nad Labem, FVTM UJEP, 230 p.

9. MÁdL J. 2012 Surface Properties in Precise and Hard Machining. Manufacturing Technology, Vol.12, No.13, p.158-166, ISSN 1213-2489.

10. MARINESCU I., et all. 2007 Handbook of Machining with Grinding wheels. Boca Raton, CRC Press,. 592 p.

11. NOVÁK M. 2011 Surface quality of hardened steels after grinding. Manufacturing Technology, Vol.11, No.11, UJEP, Ústí nad Labem, p. 55-59. ISSN 1213-2489.

12. NovÁK M. 2011 Studium jakosti brouseneho povrchu kalenych oceli, cast I. - drsnost povrchu (Study of the ground surface quality hardened steels, Part I. - surface roughness. Strojírenská technologie (Production Technology), Vol.16, No.6,. p.26-33, ISSN 1211-4162.

13. NOVÁK M. 2012 Surface with high precision of roughness after grinding. Manufacturing Technology, Vol.12, No.12,. p.66-70, ISSN 1213-2489.

14. OsIČKA K. 2009 Prüměrná aritmetická úchylka drsnosti povrchu - statistické vyhodnoceni plochy. Strojírenská technologie (Production Technology), Vol.14, No.1, p.30-3, ISSN 1211-4162.

15. RoKYTA L., LuKOviCS I. 2012 Výzkum vlivu poměrù brusiv na jakost povrchu při broušeni. (Research of the abrasives ratio influence on the surface quality when grinding). Strojírenská technologie (Production Technology),. Vol.17, No.1,2,. p. 93-95, ISSN 12114162.

16. VALÍČEK J., RuSNÁK J., MÜLler M., HRABĚ P., KADNAR M., HLOCH S., KuŠNEROVÁ M. 2008 Geometrické aspekty drsnosti povrchu klasických a netradičnich technologii (Geometrical aspects of surface roughness of classic and innovative technologies). Jemná mechanika a optika (Precision Mechanics and Optics), Vol.53, No.9, p.249-253. 